\title{
SOME OLDER SOURCES FOR CROATIAN EXONYM ANALYSIS
}

\author{
Ivana Crljenko
}

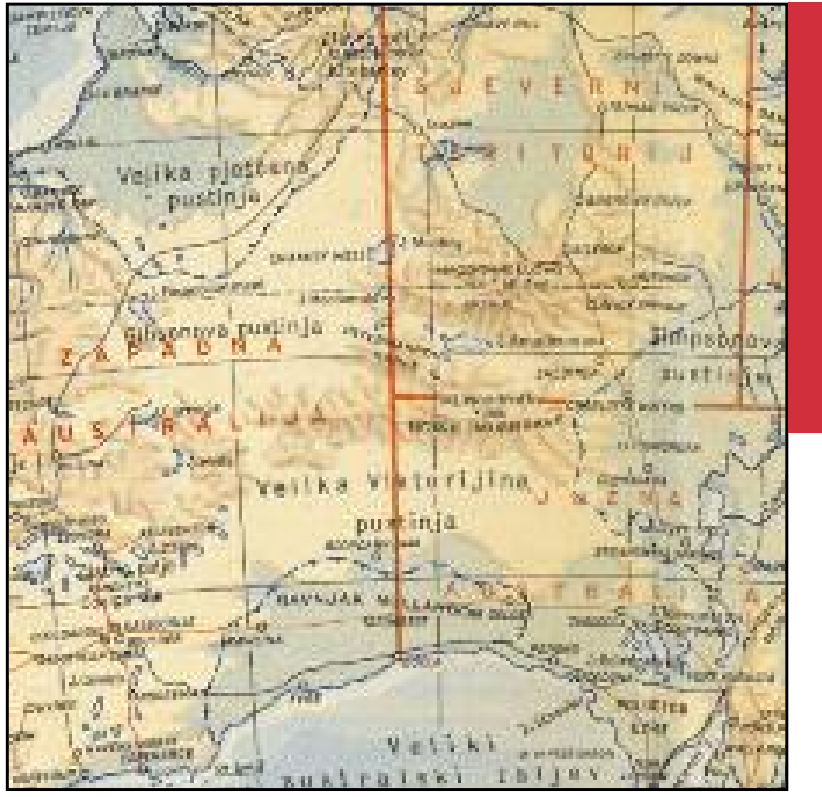

Part of the map of Australia from the Geographical Atlas (1955) showing that many geographical names were domesticated then. 


\title{
Some older sources for Croatian exonym analysis
}

DOI: http://dx.doi.org/10.3986/AGS54105

UDC: $91: 811.163 .42 ' 373.21$

COBISS: 1.01

ABSTRACT: The article introduces the review of some older sources in the Croatian language that might be useful for the Croatian exonym analysis, and may also refer to the exonym status it the context of the Croatian language development and geographers' indifference concerning that issue. Because of frequent changes in orthography, geographical names (as well as exonyms) have experienced different modifications, which can be followed through eight analyzed editions published during the period from 1880 to 1974. It was indicated that geography as a profession has greatly failed in serious research of exonyms.

KEY WORDS: geographical names, exonyms, Croatian language, orthography, geography, Croatia

The article was submitted for publication on December 4, 2012.

\author{
ADDRESS: \\ Ivana Crljenko, Ph. D. \\ Leksikografski zavod Miroslav Krleža \\ Frankopanska 26 \\ 10000 Zagreb, Hrvatska \\ E-mail: ivana.crljenko@lzmk.hr
}




\section{Introduction}

Avoiding the current discussions and dilemmas of the definition and division of endonym and exonym terms, by the term exonym in this article we refer to »the name that is used in a language for the geographical object that is situated outside the area in which the language is widely spoken (and most frequently has the official status), and the name itself is significantly different from its original, endonymic form used in the area where the object is situated (and/or in the area where this language has no official status) «(modified according to: Kadmon 2002, 2006; Woodman 2003; Kladnik 2007a, 2007b, 2007c, 2007d, 2009; Jordan 2007). Exonyms, which are also known by other terms such as domesticated or Croatized geographical names, together with the original geographical names of objects situated outside the Croatian speaking area belong to a wider group of geographical names that we can tentatively put under the common denominator of "foreign " geographical names (Kladnik 2007c, 23; in Croatian strana or tuda geografska imena). The aim of this article is to make a review of some older sources for the Croatian exonym analysis, and also to provide the insight into a broader context of the Croatian language development, especially its orthographic rules, as well as to trace the geographers' indifference concerning systematic exonymic research. The purpose of this article is to make the analyzed sources the basic groundwork for drafting the list of standardized Croatian exonyms.

\section{The methodology}

The chronological approach and text analysis of the names mostly situated on the maps have been used in this research. Eight representative geographical sources, atlases and lexicons have been singled out. Similarly, Drago Kladnik has reviewed and examined Slovenian exonyms and the results have been published in his book Podomačena tuja zemljepisna imena $v$ slovenskih atlasih sveta (»Adapted exonyms in Slovenian world atlases«, 2007b). Not only have the principal bibliographical data of every publication been introduced in the research process, but also the way of writing geographical names has been emphasized, i.e. exonyms, emphasizing the representative examples and theirs singularities. Since the analyzed editions were published between the 1880s, when the first such books appeared in the Croatian language, and 1970s, when the mass production of atlases and similar books mostly based on the translation of foreign books began to appear, this almost one century long period has been divided into four periods, depending on the temporarily dominant language politics. Apart from that, we follow the development of geography in Croatia, so we could attain the answer to the question why during this long period of time there were only few prominent Croatian geographers who very rarely addressed the issue of writing and using the exonyms in their abundant professional work.

\section{Crossing the centuries: $19^{\text {th }}$ to $2^{\text {th }}$ century}

The status of the Croatian language from the second half of the $19^{\text {th }}$ century till World War I was characterized by the struggle of four philological schools (Pranjković, 2009: 4). Contemporary orthographies mostly followed the tradition of the Zagreb philological school, which advocated the position that geographical names should be written according to the etymological, i.e. morphological principle. The pivotal characteristic of that principle is that one should not write the phonemes that are actually spoken, but should keep the root (etymon) of the word. For example, Francuz - Francuzka (French - France), Norvežanin Norvežka (Norwegian - Norway), Englez - Englezka (Englishman - England) (Barić et al. 2003, 28). The followers of the other school, named Vuk's school, issued Hrvatski pravopis (»Croatian Orthography «) written by Ivan Broz, which was an important one because it was advocating the idea of »Piši kako govoriš! « (»Write as you speak! «: Internet 1). It was the first orthography in Croatia that became obligatory for all schools. It was based on the phonological principle, but in its usage there were no extremes. Due to the lack of orthographical unity it is no wonder that we can find the reflection of mixed orthographical rules in many sources produced in that period.

The first analyzed source named Slike iz obćega zemljopisa (»The Images from General Geography«) was published in six volumes from 1888 to 1900. Nineteen European countries were described in great 


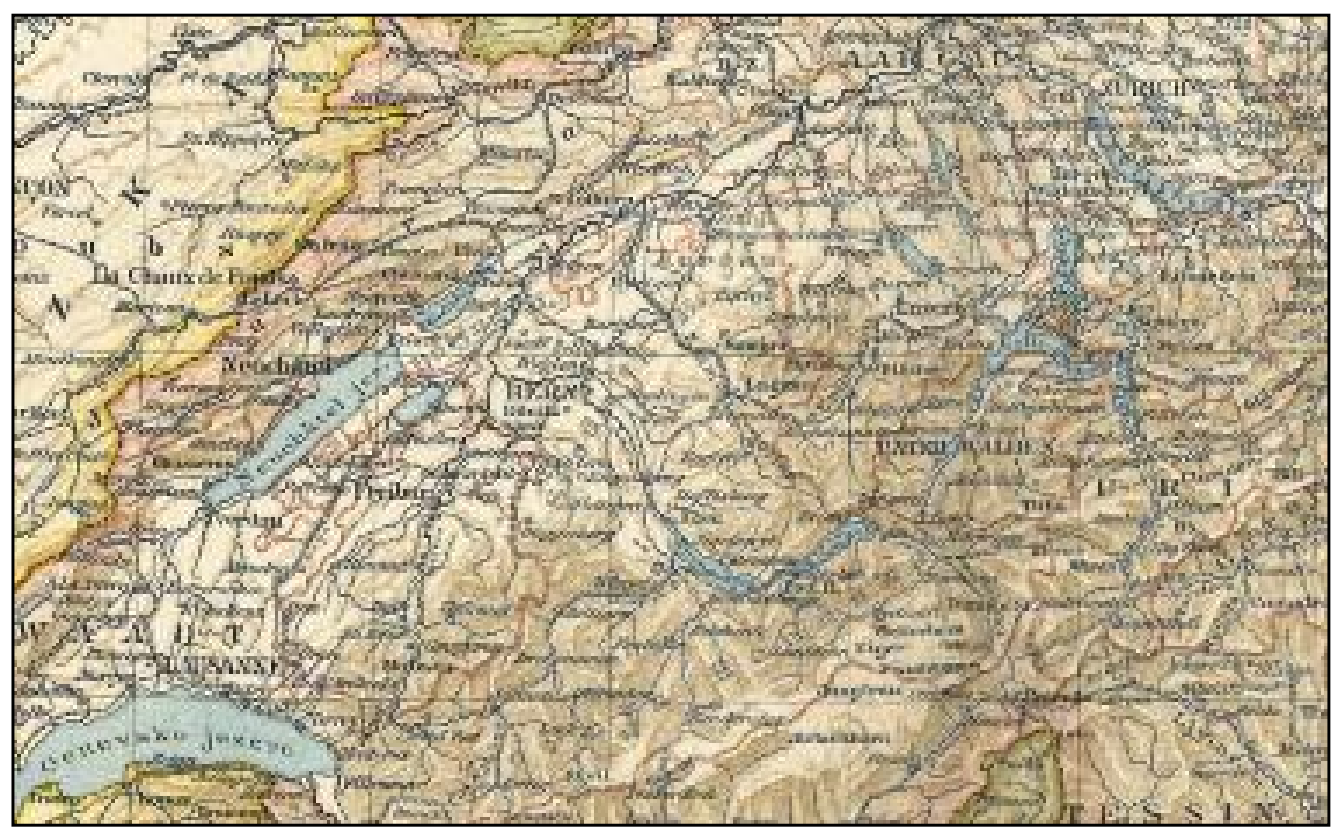

Figure 1: Map of Switzerland from The Images from General Geography showing exonymic forms of geographical names for lakes.

detail there. The books were written by Ivan Hoić who addressed mostly geographical and historical themes in his professional career. Methodologically, Hoić followed the contemporary German geographical school »the classical school «, as we call it today (Hrvatska enciklopedija, vol. 4, 606; Hrvatski biografski leksikon, vol. 5, 603-604). The mentioned volumes were issued during the period that is considered very important for the development of Croatian geography, i.e. not long after its institutionalization on the Faculty of Philosophy in Zagreb in 1883. From that moment on the first voluminous books and geographical studies about the Croatian land written by Croatian authors were being published (Feletar 1993, 6-11; Pepeonik 1996, 12-13; Magaš 2006). Producing these six volumes with dominantly geographical themes in the Croatian language was therefore a very serious and important event in the first years after the foundation of geography as an institutionalized science.

Concerning the topic of writing geographical names, Hoić has very often used Croatized names, e.g. Francuzka (France), Spljet (Split), Marselj (Marseille), Portugalska (Portugal), Mletci (Venice), Iztočna Rumelija (East Rumelia), Genovezki zaliv (the Genoa Bay), Bielo more (the White Sea), Osiek (Osijek), Bukarešt (Bucharest), Budapešta (Budapest), Bruselj (Brussels), Jermenija (Armenia), Bristolski kanao (the Bristol Channel). On the other hand, some geographical names for which we nowadays usually use Croatized, domesticated forms, were then written in the forms more similar to the original ones, e.g. Athena (originally Athína, English Athens), the state of Algir (originally al-Jazā'ir, English Algeria), Oporto (originally and in English Porto), Firenza (originally Firenze, English Florence). That is the outcome of a started but not yet finished process of geographical names domestication. However, concerning the fact that Hoić applied a very courageous approach of domesticating many still unaccepted geographical names, we can consider his books one of the earliest comprehensive sources for the Croatian exonym analysis.

\section{Between the two world wars}

During the period between 1918 and 1941 many Croatian writers were impressed by the new Yugoslav enthusiasm and therefore started writing in ekavian pronunciation, but most of them returned to ijekavian pronunciation at the beginning of the 1920s. As part of strong endeavors in unifying the Croatian and Serbian standard languages, Pravopis srpskohrvatskog jezika (»Serbo-Croatian Orthography«) by 
Aleksandar Belić was officially introduced (Barić et al. 2003, 34-35). In wider usage there was also Pravopisno uputstvo za sve osnovne, srednje i stručne škole Kraljevine SHS (»Orthographical Instructions for all Primary, Secondary and Professional Schools in the Kingdom of Serbs, Croats and Slovenens«) issued in 1929, according to which the names should be written phonetically or originally, the latter in the cases where the pronunciation of names was very distinct from the original versions. However, the frequency of usage of the mentioned rules in practice is evident from the following sources.

Leksikon Minerva - praktični priručnik za modernog čovjeka (»Minerva Lexicon - a Practical Handbook for a Modern Man«) was the second source we analyzed. In its preface the Lexicon is introduced as "... not only the first ours, but also generally the first lexicon in the Slavic South ... «It was published in 1936. In 1583 pages the Lexicon contains 54000 terms and 8 maps, 2297 illustrations and 38 tables.

Due to a rather vague explanation of rules for writing geographical names, in the Lexicon we can find many variants of geographical names. For example, we can find country names such as: Nicaragua, Costarica, Colombija (Columbia), Chile, Bolivia, Uruguay, New Zealand, Romania, Španija (Spain), Abesinija (the Ethiopian Empire, Abyssinia) or Canada, from which we can conclude that some country names had already gained their Croatian form, while others had not. We can also notice different hybrids in the names of seas, oceans, channels, mountains or regions: Koralno more (the Coral Sea), Arafura more (the Arafura Sea), Tasman-more (the Tasman Sea), Banda-more (the Banda Sea), Bassov put (the Bass Strait), Cookov put (the Cook Strait), Hudson Bay, Tripolitanija (Tripolitania), Grǿnland (Greenland), or Alaska, so it seems that many geographical names had not been totally Croatized yet. The result was the appearance of a sort of semi-Croatized mixed names that consisted of a translated appellative, and not translated proper names, i.e. left in their original form, such as: Barents-more (the Barents Sea), Timor-more (the Timor Sea), Ural-gorje (the Ural Mountains).

The first comprehensive world atlas in the Croatian language, Minervin svjetski atlas (»Minerva's World Atlas «) was published in 1938. The editors were the geographers Filip Lukas and Nikola Peršić. Filip Lukas was a geographer, but also historian and theologian. He was especially interested in geopolitics, and was

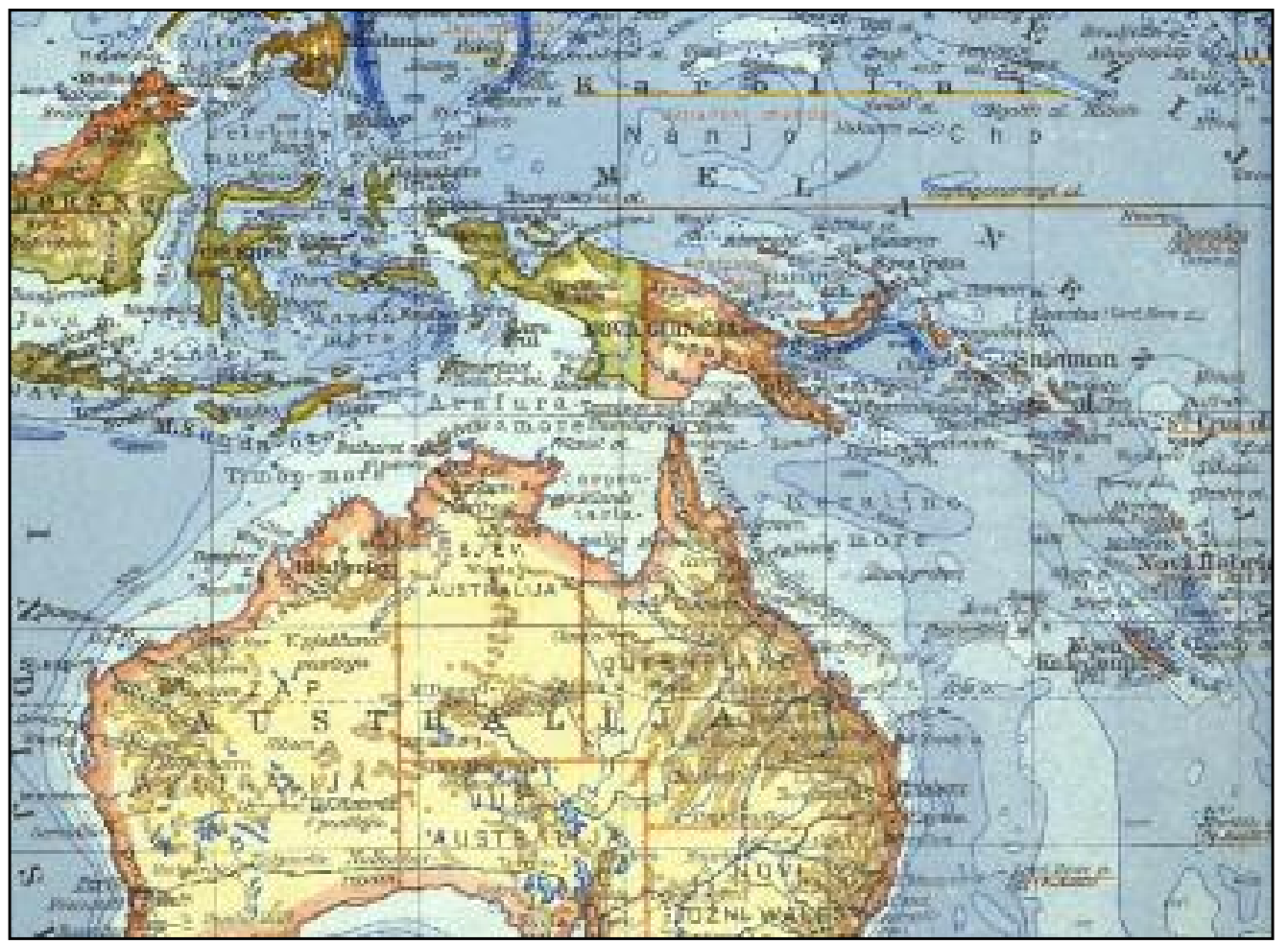

Figure 2: On the map of Australia and Oceania from the Minerva's World Atlas we can notice semi-Croatized forms of some sea names. 


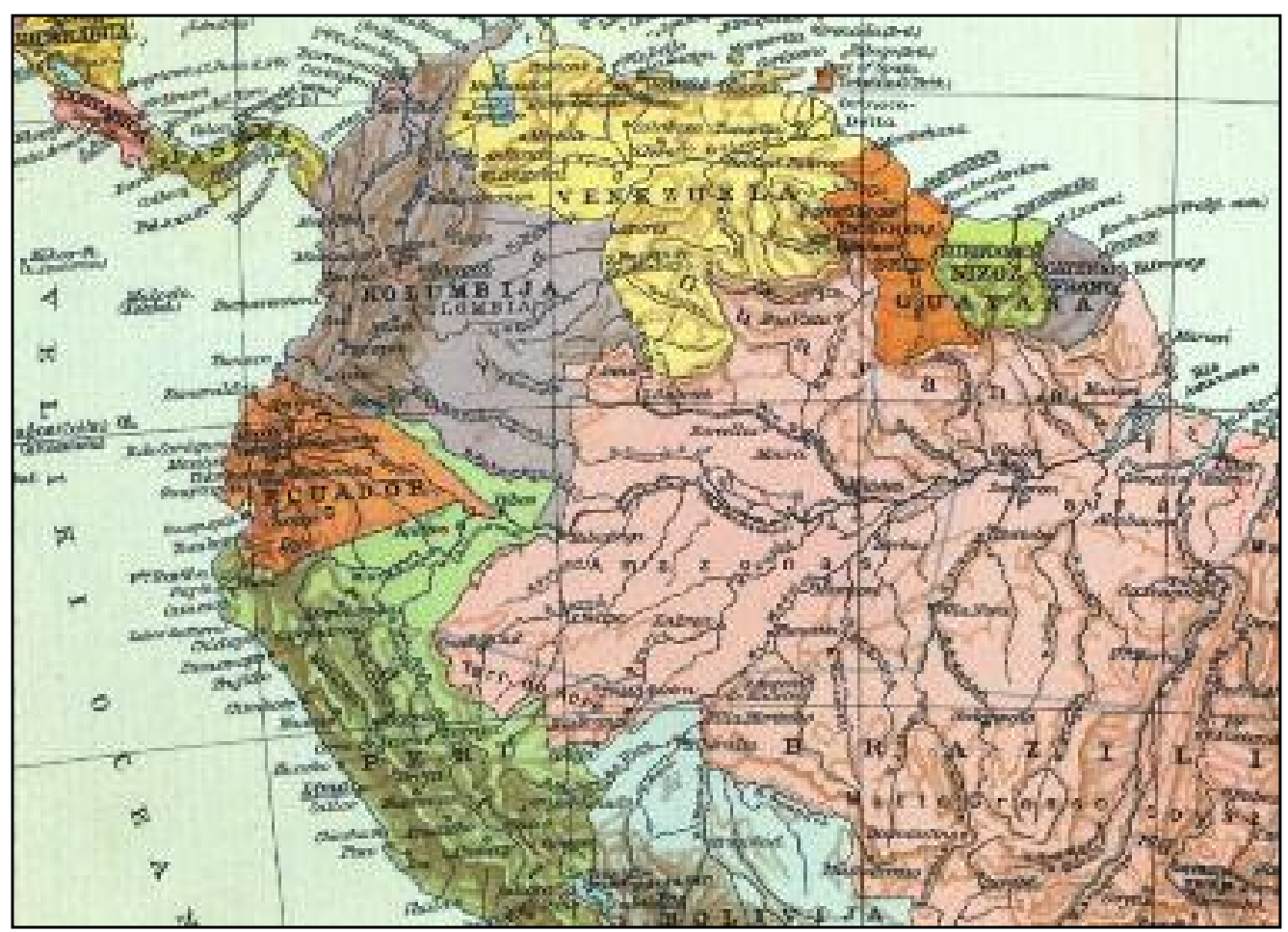

Figure 3: In Minevra's World Atlas the process of exonymization partly overtook country names, which is seen on the example of South America.

addressing the topics within economic, regional and political geography, as well as lexicography (Hrvatska enciklopedija, vol. 6, 680-681; Magaš 2007, 157). Nikola Peršić was practising both economic geography and demography (Magaš 2007, 157). Both of them were professionally engaged in the period between the two world wars, when the number of published books dealing with geographical issues significantly increased. However, these books were mostly foreign ones. Only in the later years of that period some Croatian geographers distinguished themselves from the others (Feletar 1993, 11-12; Pepeonik 1996, 13; Magaš 2006).

Minervin svjetski atlas includes 169 textual pages and 50 colored maps (i.e. 110 main and "auxiliary" maps); it offers an overview of the world on the eve of World War II. In the last pages of the book there is a very detailed and systematic geographical names index, which makes this atlas an extremely alluring source for the exonym analysis.

Concerning writing exonyms, in the preface we can read: »A small number of names of large towns and rivers for which we have traditional domesticated names (such as: Beč (Vienna, author's comment), Rim (Roma, author's comment), Mleci (Venice, author's comment), Rajna (the Rhine, author's comment), Laba (the Elbe, author's comment) and so on), are being left as they are, together with the original names in the parentheses, for example Beč (Wien). «Lukas and Peršić pointed out that »... despite our best will, somewhere ... we had to recede from some principles for many reasons, because the absolute consistency would often be unsuitable."

\section{Period of the ISC (1941-1945)}

As an opposition to the Yugoslav linguistic trends, whose main tendency was homogenization of the languages during the period between the two world wars, in the period of the Independent State of Croatia (ISC) the old Croatian linguistic tradition and reimplementation of the orthography based on keeping the root of the word came into life again. This time the morphological principle was applied literally (Barić et al. 2003, 35). Namely, the new government of the »ustaša " wanted to remove »... all Serbized words 
imposed between 1918 and $1941 \ldots$ (Samardžija 2008, 43). The most important document of the linguistic politics was Zakonska odredba o hrvatskom jeziku, o njegovoj čistoći i o pravopisu (»Legal Regulation of the Croatian Language, Its Purity and Orthography«; Samardžija 2008, 45). New Hrvatski pravopis (»Croatian Orthography«) by the authors Franjo Cipra and Adolf Bratoljub Klaić was also written in 1944.

The reference source for this period was Poviestni zemljopis Evrope (»A Historical Geography of Europe «). It is a translation of the original An Historical Geography of Europe by the author Gordon East published in 1944, with the index of geographical names in the end of the book. It is one of the oldest translated books of historical and political geography. Since there is a considerable lack of maps in the book, geographical names mainly appear in the textual part. It was noticed that the exonymic forms of the names were used in large extent, such as: Kampanja (Campania), Tiber (the Tiber), Eufrat (the Euphrates), Andaluzija (Andalusia), Galipolje (Gallipoli), Mađarska(Hungary), Bavarija(Bavaria), Ženevsko jezero (Lake Geneva), Daleki Iztok (the Far East), Englezka (England), Flandrija (Flanders), Katalonija (Catalonia), Solun (Thessaloniki), Šlezija (Silesia), but we can also find semi-Croatized names such as Macedonija (Macedonia) or Toscana (and Toskana; Tuscany). Since the root based orthography was being literally applied, many geographical names from this source look very archaic from today's viewpoint, e.g. Englezka (modern Engleska; England), Francuzka (modern Francuska; France), Norvežka (modern Norveška; Norway).

\section{After World War II}

After reaching the so called »Novi Sad Agreement « in 1954, the Croatian language became equal and united with the Serbian and Montenegrin languages (Barić et al. 2003,35). A mutual orthography was issued in 1960, based on the phonological principle according to Pravopis hrvatskosrpskoga književnog jezika (»Orthography of the Serbo-Croatian Standard Language«) from 1958.

Conceived in this way, the unity of language, together with the »Novi Sad Agreement " and new orthography, were rejected by the »Declaration on Language " (full name »The Declaration on the Status and Name of the Croatian Standard Language «) from 1967, the outcome of which was the appearance of Hrvatski pravopis (»Croatian Orthography«) by the authors Stjepan Babić, Božidar Finka and Milan Moguš in 1971. Besides some others, we have used this orthography handbook till today. Although it especially accentuates the problems of writing exonyms, its main disadvantage is that while explaining the ways of writing exonyms, there are just a few examples for it, and those are generally the uncontested ones. For instance, on page 69 of the 1994 edition as the examples of region names and country names there are: Albanija (Albania), Austrija (Austria), Bavarska (Bavaria), Bugarska (Bulgaria), Čška (the Czech Republic), Danska (Denmark), Engleska (England), Etiopija (Ethiopia), Grcka (Greece), Indija (India), Irska (Ireland) ... while disputable names such as Kapverdski Otoci (Cape Verde), Maldivi (the Maldives), Mijanmar (Myanmar) are not even mentioned, which leaves room for arbitrary interpretations of writing geographical names that are not given in the book (Crljenko, Klemenčić 2011, 108).

In the analysis, this period is primarily represented by Geografski atlas i statisticko-geografski pregled svijeta (»Geographical Atlas and Statistical-Geographical Overview of the World«). We have analyzed its fourth edition from 1955; the first edition was issued in 1951. The editors were Petar Mardešić and Zvonimir Dugački, while the technical editor of the maps was Josip Zoričić. Petar Mardešić was a sailor, lexicographer, cartographer and publisher. He was a contributor to the Pomorska enciklopedija (»Naval Encyclopaedia«), and also the editor-in-chef of many atlases published by the Lexicographical Institute (Hrvatska enciklopedija, vol. 7., 58; Magaš 2007, 158). Prior to all his interests, Zvonimir Dugački was a geographer and cartographer. He was addressing the themes within the anthropogeography and regional geography and was also an author of many geographical and historical school maps (Hrvatska enciklopedija, vol. 3, 292; Hrvatski biografski leksikon, vol. 3, 659-660; Magaš 2007, 157). The productive scientific and professional work of both editors was accomplished in the period of a serious consolidation in the organization of Croatian geography, i.e. its actual shifting to the Faculty of Science. By doing so, new, more favorable conditions for its literature enrichment appeared (Feletar 1993, 12-16; Pepeonik 1996, 13-17; Magaš 2006). Apart from that, the Lexicographical Institute of the Federal People's Republic of Yugoslavia was established in 1950, which made a stable foundation for a serious scientific and professional lexicographical work based on the merits. Besides Mardešić and Dugački, some other prominent geographers were also permanent contributors with the Institute, such as: Oto Oppitz, Josip Roglić, Ivan Rubić, Veljko Rogić. 


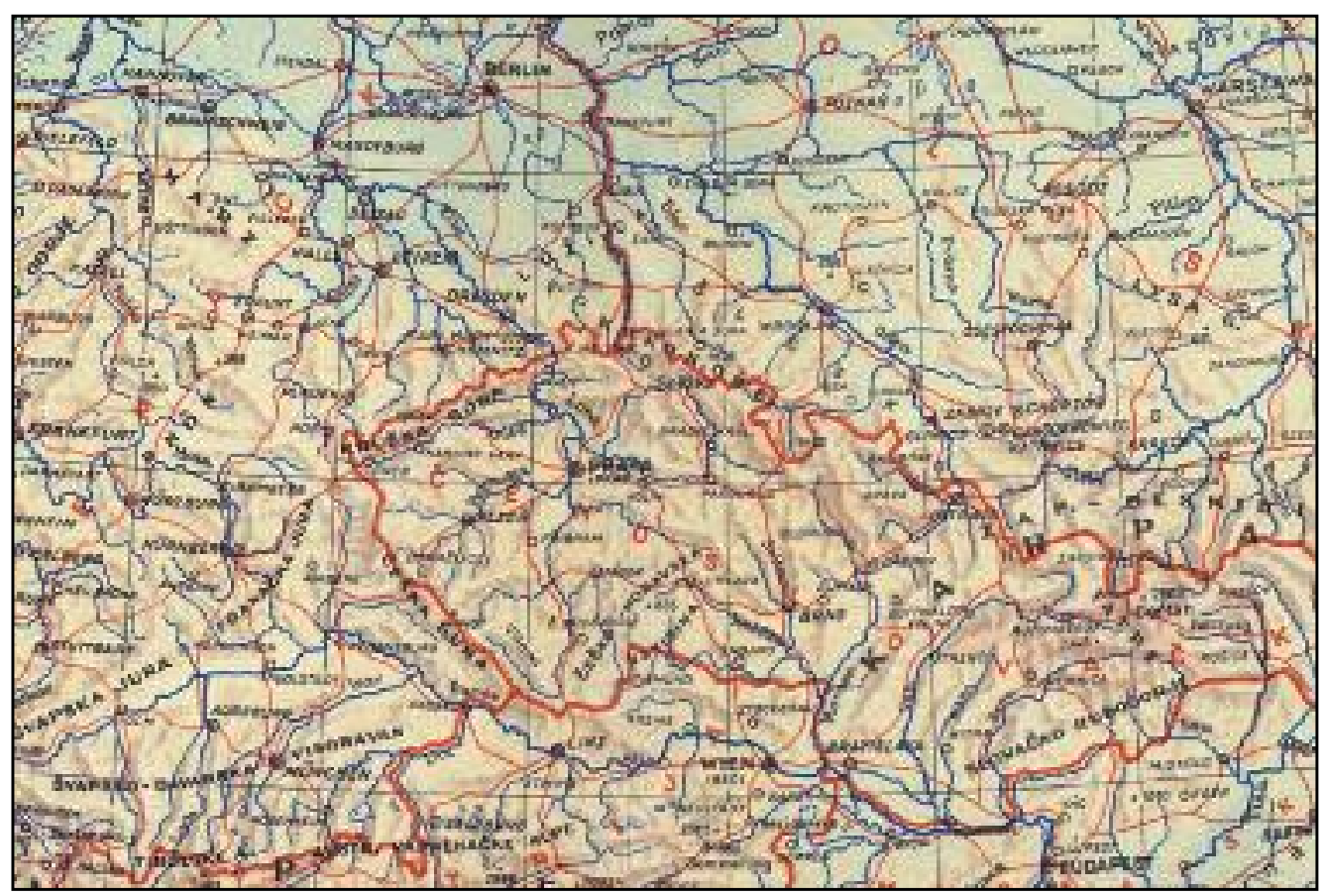

Figure 4: Map of Central Europe in the Geographical Atlas and Statistical-Geographical Overview of the World showing the unequal status of domesticated town names in respect to the original names.

In their lexicographical work they all surely had to address the problems of writing exonyms. Therefore since then geographers started to think of exonyms as a serious topic, at least of the issues concerning their usage on maps and in texts.

Geografski atlas $i$ statisticko-geografski pregled svijeta includes 50 colored general geographical maps and an alphabetical index of geographical names in the end of the book. By comparing the maps, it was observed that in some cases geographical names were written exclusively in their exonymic forms, such as Prag (Prague), Beč (Vienna), Budimpešta (Budapest), while in some other cases both forms were used, e.g. Atene (Athinai; Athens), Rim (Roma; Rome), Praha (Prag; Prague), Warszawa (Varšava; Warsaw). Such a situation gives us the right to imply that the makers of the maps had many difficulties in the implementation of rules for writing geographical names in practice. Nevertheless, exonyms began to be used in larger extent than before. For example, Kalifornija (California) was written in its exonymic form back then, so that it could later be written as California, and again Kalifornija. On the map of the United States of America, on the other hand, we could find rendered names for Južna (South) and Sjeverna Karolina (North Carolina), but also Texas and New Mexico, and a mixed name between an endonym and a full exonym Virginija (Virginia). As opposed to the still disputable names of regions, federal states and towns, the names of seas and bays gained their full adjectival forms.

The next examined source was Enciklopedija Leksikografskog zavoda (»Encyclopaedia of the Lexicographical Institute«). For the purpose of this analysis we have reviewed its first edition, which was published in seven volumes between 1955 and 1964. Two longtime Institute associates were involved in the process of making this Encyclopaedia, Oto Oppitz and Veljko Rogić, as the chief geographical editors. Oto Oppitz was a geographer and lexicographer, a physical geographer by vocation. He was also a permanent contributor and editor in many geographical and cartographical editions published by the Institute, such as Pomorska enciklopedija (Hrvatska enciklopedija, vol. 8, 112).Veljko Rogić is a geographer whose interests are mostly connected with regional, historical and political geography (Hrvatska enciklopedija, vol. 9, 396; Magaš 2007, 185). 
The analysis of exonyms showed that most hydronyms and some (but not all!) names of regions were Croatized, for example Australian federal states Novi Južni Wales (New South Wales) and Zapadna Australija (Western Australia). A portion of the Croatized geographical names in Enciklopedija, similarly as in the other Institute's editions issued in the 1950s and 1960s, can be considered very remarkable compared to the publications that followed. Whether intuitively, whether because of the general internationalization and therefore increased necessity for the endonym use, and probably under the influence of a better familiarity of map makers with the global trends in the development of the exonym idea (especially concerning the $29^{\text {th }}$ resolution of the Second UN Conference on the Standardization of Geographical Names held in 1972; Internet 2), a portion of exonyms in the following editions considerably decreased.

Oto Oppitz and Petar Mardešić were the chief editors of the first edition of Atlas svijeta (»World Atlas «) published by the Lexicographical Institute of the Federal People's Republic of Yugoslavia in 1961. There are 200 pages of geographical maps and an index that includes about 51000 geographical names in the end of the book.

The exonym analysis in Atlas svijeta implicated that exonyms were used in a large extent. When being the oikonyms, exonyms had an advantage over the endonyms, so they were written on the place with larger fonts and then the endonyms followed, written in the parentheses in smaller fonts, e.g. Beč (Wien; Vienna), Budimpešta (Budapest), Prag (Praha; Prague). This kind of practice was abandoned later, so in the latest edition ( $7^{\text {th }}$ edition) the practice is reversed.

The last reviewed source was Veliki atlas svijeta (»Great World Atlas«), which was issued in 1974 as both Slovene and Croatian (Serbian) volume. The editor-in-chief for the Croatian edition was a geographer, author and editor of the school literature and atlases Alfonso Cvitanović (Hrvatski biografski leksikon, vol. 2,773-774). Veliki atlas svijeta offers the abundance of general geographical maps and thematic maps, as well as a textual and tabular appendix for the entire world, continents, parts of the world and countries. The book ends with an index of geographical names.

A whole chapter in the Atlas, the one between pages 392 and 399, is devoted to geographical names, which was not the case before. In that chapter the editor explains the major problems of writing and reading geographical names in great detail. That is the reason why this text might be considered as one of the most

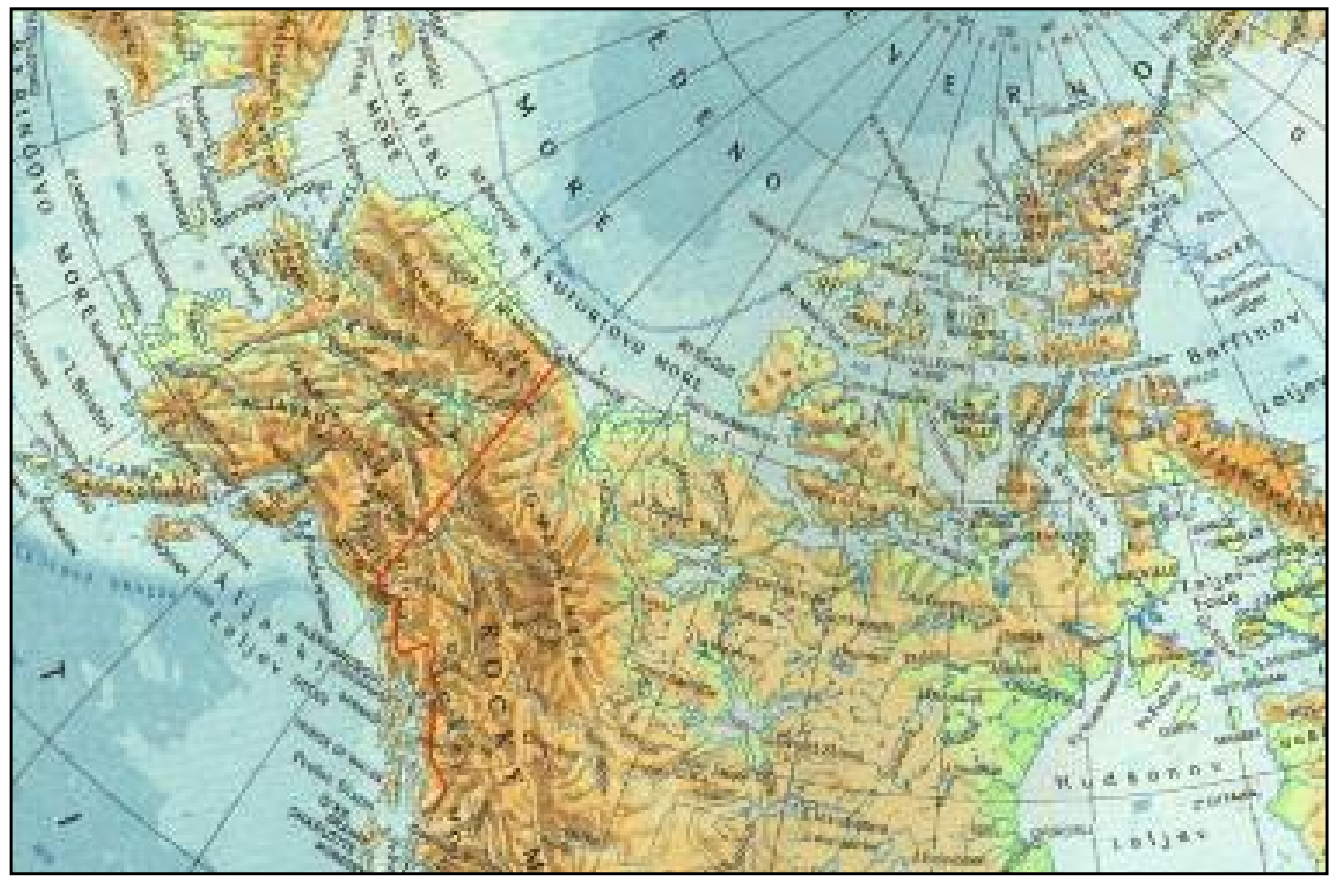

Figure 5: Domesticated names of seas, bays, islands and mountains on the map of North America in the World Atlas. 
influential texts about the aforementioned topic. Not only does he argue the key dilemma of the map and atlas makers (whether to adopt the original name, and if so which one, or to accept the name that is domesticated), but he also refers to the international practice of treatment of geographical names, and emphasizes the problems of inconsistent writing of geographical names, the problems that are discussed even today (see more in: Crljenko 2008). The latter is the result of an absence of scientifically embedded body that would be engaged in the issues of geographical nomenclature (Cvitanović's criticism was initiated in 1974!) (see more in: Faričić 2003; Crljenko 2008). In the exonym-endonym relation he gives priority to endonyms (on maps the exonyms are written in the parentheses, e.g. Roma (Rim; Rome), Napoli (Napulj; Naples), Trieste (Trst)).

Cvitanović also accentuates the problem of inconsistency of our orthography (he was using Pravopis hrvatskog književnog jezika (»Orthography of the Croatian Standard Language « from 1960), the problem that is being alerted to even today (Crljenko 2012). The insight into the mentioned orthography handbook makes him wonder: »... why should we exclude 'only domesticated names such as Prag (Prague, author's comment), Varšava, (Warsaw, author's comment), Poznanj (Poznan, author's comment), Laba (the Elbe, author's comment), Odra (the Oder, author's comment) and so on'?... Why should we render the name Teutoburška šuma (the Teutoburg Forest, author's comment), and use an untranslated name Schwarzwald?... In such cases the explanation that 'these names were adapted to our language ages ago', which we can find in the orthography book, does not help."

\section{Key observations on the exonyms in the analyzed editions}

According to the analysis of the chosen sources and by comparing the status of exonyms, its characteristics and the manners of writing and its usage, we have reached the following observations:

- The way of writing and the usage of exonyms are usually prescribed by the orthography rules, so as these rules changed, the characteristics of the foreign geographical names changed, too. The Croatian language and its orthography, as well as its exonyms, have been influenced by the political situation too often.

- The examples introduced in the orthography are very seldom and they are almost always the uncontested ones, so it often seems that there is no point in bringing up the rules for writing the geographical names at all. There are too many geographical names the writing of which stays unclear even after consulting the orthography.

- The earlier orthographies, prefaces or introductory chapters in the analyzed editions paid little attention to the explanations regarding writing foreign geographical names. When the practice improved, the writing became somewhat more uniformed.

- Between the two world wars sorts of mixed names between exonyms and endonyms appeared, i.e. semi-Croatized hybrid forms, especially hydronyms, which later adopted the full exonymic forms by translation or adjectival adaptation.

- Inconsistency noticed on the maps and in the texts inside the same publication is the result not only of abundance of geographical names, but also of both unclear treatment and the manners of writing geographical names. This was usually the case in the periods of transition from the original to the exonymic form of the names (e.g. in the oldest analyzed sources), especially after passing a resolution about reducing the number of exonyms, after which geographical names started to adopt their original forms again.

- Depending on the form the priority is given to (earlier to exonyms, later to endonyms), in some sources exonyms are written as the heading entries in the text or in the first place on the maps, while endonyms are written in the parentheses. In other sources, usually the newer ones, it is vice versa.

- The exonyms that have existed in the Croatian language for a long time and have therefore become part of our everyday communication, such as Beč (Vienna), Budimpešta (Budapest) or Trst (Trieste), appear in their exonymic form in all analyzed sources, no matter where they stand. Troubles arise with the exonyms that were not totally domesticated by the time of the publication of the mentioned sources, such as Teksas (Texas), Sjeverna Dakota (North Dakota), Južna Australija (South Australia), Šangaj (Shanghai) and so on. Therefore we can find them written in both ways.

- The review of geographical names in all examined editions indicated that the stage of exonymization depends on the type of geographical feature, so country names have become totally domesticated with time, while the names of towns and territorial units have been Croatized to a much lower extent. The names of seas, bays, rivers and so on have also been partially domesticated, often by translation or by using adjectival forms. However, there are many exceptions that we cannot understand. 


\section{Conclusion}

When and if the problem of writing exonyms is discussed in Croatia, it is usually not about when to use an exonym and/or an endonym, but how to write one and why we cannot find it written in the same way in all of literature. The problems that arise from inconsistent and non-standardized writing of exonyms are indeed widespread in Croatia (Crljenko 2008), although many other languages have to deal with similar issues as well (Kladnik 2005; Kladnik an Bole). Such a chaotic situation in which one cannot be sure how to write a specific Croatized geographical name (and whether to domesticate an original name in the first place), seems to be a direct outcome of the deficiency of the orthographical rules, as well as the absence of a unique standardized list of exonyms. The latter one is the result of the absence of a commission that would seriously and frequently be engaged in the subject matter of geographical names, not just the problems with exonyms.

Analyzing the treatment, form and use of geographical names (and exonyms) in the chosen sources, we can say that geographical names have been significantly influenced by the development of the Croatian language. Though geographical names, as well as exonyms, should undoubtedly be examined and analyzed from the interdisciplinary point of view of several sciences, "... in Croatia those are (exonyms, author's comment) almost exclusively treated as an orthographical problem ... «(Brozović Rončević 2011). Considering the obvious and indisputably strong relationship between language, orthography and geographical name, it is no wonder that Croatian linguists have gone furthest in the studies of geographical names. From 2005 to 2012 they were assembled in Vijeće za normu hrvatskoga standardnog jezika (»Council for the Standard Croatian Language Norm«), with the aim of standardizing language, geographical names, too (Brozović Rončević 2011). The process of exonym standardization has gone furthest in exonymization of country names and dependent territories, so on the official level Abecedni popis država i zemalja i njihovih ozna$k a$ (»Alphabetical list of countries and territories and their markings«; Internet 3 ) is being used.

To a much lesser extent, if at all, the use and treatment of geographical names have been influenced by the development of Croatian geography, which should certainly have a more important role regarding toponymy. Unfortunately, geographers have not been systematically analyzing and systematizing geographical names so far. All geographers mentioned in this article mainly brought to consciousness the problems of writing geographical names at the time they were involved in the lexicographical work. Apart from rare exceptions, the enthusiasm of other geographers concerning this topic has been even lesser. Certainly, that does not mean that geographers are unaware of the problems that arise in writing and pronunciation of exonyms. Nevertheless, it seems that the topic is not very challenging for them, or they think they have too little to say about it (which cannot be more wrong!), or they are simply oriented to other, »more geographical« themes. We will see if this kind of disinterest in the problems of geographical names among the Croatian geographers will soon be changed.

\section{References}

Atlas svijeta. Leksikografski zavod FNRJ Zagreb, 1961.

Babić, S., Finka, B., Moguš, M. 1971, 1994: Hrvatski pravopis. Zagreb.

Barić, E., Lončarić, M., Malić, D., Pavešić, S., Peti, M., Zečević, V., Znika, M. 2003: Hrvatska gramatika. Zagreb.

Broz, I. 1892: Hrvatski pravopis. Zagreb.

Brozović Rončević, D. 2011: Exonyms as a reflection of cultural heritage. The twentieth session of the East Central and South-East Europe division of the UNGEGN. Zagreb, 9-11.2.2011. Internet: http://ungegn.dgu.hr/ungegn20/27_CRO_ECSEED_Documets_Brozovic_Exonyms.pdf (12.11.2012).

Cipra, F., Klaić, A. B. 1944: Hrvatski pravopis (uz suradnju članova Ureda za hrvatski jezik). Zagreb.

Crljenko, I. 2008: O pisanju geografskih imena: Neke nedoumice u hrvatskim leksikografskim i kartografskim djelima. Studia lexicographica 1-2.

Crljenko, I. 2012: Geographical feature importance as a criterion for exonym selection: Croatian Examples. The great toponymyc divide. Warszawa.

Crljenko, I., Klemenčić, M. 2011: Geografska imena u leksikografskim izdanjima. Zbornik radova Prvog nacionalnog znanstvenog savjetovanja o geografskim imenima. Zadar. 
East W. G. 1944: An historical geography of Europe. Zagreb.

Enciklopedija Leksikografskog zavoda 7. Zagreb, 1955-1964.

Faričić, J. 2003: Je li u Hrvatskoj potrebno povjerenstvo za geografska imena? Internet: http://www.geografija.hr/ clanci/60/je-li-hrvatskoj-potrebno-povjerenstvo-zageografska imena (14.10.2003).

Feletar, D. 1993: Pregled razvoja geografije u Hrvatskoj - uz 110. obljetnicu katedre za geografiju u Zagrebu. Acta geographica Croatica 28.

Geografski atlas i statističkoč-geografski pregled svijeta. Seljačka sloga. Zagreb, 1955.

Glossary of Terms for the Standardization of Geographical Names. UNGEGN, United Nations Publication. New York, 2002.

Hoić, I. 1888-1900: Slike iz obćega zemljopisa 1-5. Zagreb.

Hrvatska enciklopedija, sv. 3, 4, 6, 7, 8, 9. Zagreb, 2001, 2002, 2004, 2005, 2006, 2007.

Hrvatski biografski leksikon 2, 3, 5. Zagreb, 1989, 1993, 2002.

Internet 1: http://webograd.tportal.hr/Miha29/hrvatskijezik/kratkapovijesthrvatskogajezika (12.11.2012).

Internet 2: http://unstats.un.org/unsd/geoinfo/ungegn/docs/2nd-uncsgndocs/e_conf_61_4_en.pdf (13.9.2012).

Internet 3: http://www.nn.hr/clanci/sluzbeno/1994/0840.htm, http://www.nn.hr/clanci/sluzbeno/2001/ 1840.htm (20.11.2012).

Jordan, P. 2007: Considerations on the definitions of »endonym« and »exonym«. Exonyms and the international standardisation of geographical names. Wien.

Kadmon, N. 2006: Exonyms, also called conventional names. Manual for the national standardization of geographical names. New York.

Kladnik, D. 2005: Geografov pogled na tuja zemljepisna imena v Slovenskem pravopisu 2001. Geografski vestnik 77-2.

Kladnik, D. 2007a: Characteristics of Exonym Use in Selected European Languages. Acta Geographica Slovenica 47-2. DOI: http://www.dx.doi.org/10.3986/AGS47203

Kladnik, D. 2007b: Podomačena tuja zemljepisna imena v slovenskih atlasih sveta. Geografija Slovenije 14. Ljubljana.

Kladnik, D. 2007c: Pogledi na podomačevanje tujih zemljepisnih imen. Georitem 2. Ljubljana.

Kladnik, D. 2007d: Prispevek k poenotenju rabe podomačenih tujih zemljepisnih imen v slovenskem jeziku. Geodetski vestnik 51-3.

Kladnik, D. 2009: Semantic Demarcation of the Concepts of Endonym and Exonym. Acta Geographica Slovenica 49-2: DOI: http://dx.doi.org/10.3986/AGS49206

Kladnik, D., Bole, D. 2012: The life of Slovenian exonyms and their familiarity in the professional community. Acta geographica Slovenica 52-2. DOI: http://dx.doi.org/10.3986/AGS52204

Leksikon Minerva - praktični priručnik za modernog čovjeka. Zagreb, 1936.

Magaš, D. 2006: Kratak prikaz razvoja hrvatske geografije. Internet: http://www.geografija.hr/clanci/977/ kratak-prikaz-razvoja-hrvatske-geografije (6.11.2006).

Magaš, D. 2007: Geografija i geografi na visokoškolskim ustanovama u Hrvatskoj izvan Prirodoslovnomatematičkog fakulteta u Zagrebu. Geoadria 12-2.

Minervin svjetski atlas. Minerva nakladna knjižara d. d., Zagreb, 1938.

Pepeonik, Z. 1996: Razvoj geografije u Hrvatskoj od njene institucionalizacije do danas. Zbornik radova Prvog hrvatskog geografskog kongresa. Zagreb.

Pranjković, I. 2009: Hrvatski jezik u 19. st. Internet: http://www.hrvatskiplus.org/prilozi/dokumenti/ anagram/Pranjkovic_Hrvatski.pdf (12.9.2012).

Pravopisna komisija: Pravopis hrvatskosrpskoga književnog jezika. Zagreb, 1958.

Pravopisno uputstvo za sve osnovne, srednje i stručne škole Kraljevine SHS s kratkim tumačenjem i objašnjenjem. Zagreb, 1929.

Samardžija, M. 2008: Hrvatski jezik, pravopis i jezična politika u NDH. Zagreb.

Veliki atlas svijeta. Prosveta i Mladinska knjiga. Beograd, Ljubljana, 1974.

Woodman, P. 2003: The UNGEGN Definitions of »Endonym« and »Exonym». Working Group on Exonyms. Prague. Internet: http://www.zrcsazu.si/wge/Documents/Papers\%20Prague/Woodman_Exonyms\%201.pdf (25.3.2008). 